\title{
Autologous Peripheral Blood Mononuclear Cells
}

National Cancer Institute

\section{Source}

National Cancer Institute. Autologous Peripheral Blood Mononuclear Cells. NCI

Thesaurus. Code C135058.

A preparation of autologous peripheral blood mononuclear cells (PBMCs). 